\title{
IMPLEMENTASI METODE PEMBELAJARAN TWO STAY TWO STRAY UNTUK MENINGKATKAN KEAKTIFAN DAN HASIL BELAJAR TEKNOLOGI DASAR OTOMOTIF SISWA KELAS X TKRB SMKN 1 SEDAYU
}

\author{
Febryan Edwin Nur Ramadhan* \& Wardan Suyanto \\ Pendidikan Teknik Otomotif, Universitas Negeri Yogyakarta \\ *E-mail: febryan.edwin2015@student.uny.ac.id
}

\begin{abstract}
ABSTRAK
Penelitian ini bertujuan untuk meningkatkan keaktifan dan hasil belajar siswa di SMK N 1 Sedayu pada mata pelajaran Teknologi Dasar Otomotif melalui implementasi metode pembelajaran two stay two stray. Jenis penelitian ini adalah penelitian tindakan kelas dan dilaksanakan selama dua siklus penelitian. Desain penelitian pada setiap siklus menggunakan empat langkah/tahapan dari penelitian tindakan kelas yaitu, (1) perencanaan, (2) pelaksanaan, (3) observasi, dan (4) refleksi. Subyek penelitian adalah siswa kelas X TKR B SMK N 1 Sedayu pada semester genap tahun ajaran 2018/2019. Pengambilan data dilakukan melalui lembar observasi untuk mengetahui keaktifan siswa, dan mengamati pelaksanaan metode two stay two stray, serta tes evaluasi untuk mengetahui tingkat hasil belajar siswa. Implementasi metode two stay two stray dikatakan berhasil meningkatkan keaktifan dan hasil belajar apabila persentase keaktifan mencapai 70\% (kategori baik) dan sebanyak 75\% siswa telah tuntas KKM (kategori baik) yaitu nilai hasil belajar minimal 75. Hasil penelitian menunjukkan bahwa implementasi metode two stay two stray pada proses pembelajaran dapat meningkatkan keaktifan dan hasil belajar siswa kelas X TKR B SMK N 1 Sedayu. Hal ini terbukti pada siklus II persentase keaktifan dan ketuntasan hasil belajar telah mencapai indikator keberhasilan yang ditentukan dengan persentase keaktifan mencapai 76\% (kategori baik) dan jumlah siswa tuntas KKM mencapai $81 \%$ (kategori sangat baik).
\end{abstract}

Kata kunci: Keaktifan, Hasil Belajar, Two Stay Two Stray, PTK.

THE IMPLEMENTATION OF TWO STAY TWO STRAY LEARNING METHODS TO

IMPROVE THE ACTIVENESS AND THE LEARNING OUTCOMES IN BASIC

TECHNOLOGY OF AUTOMOTIVE COURSE OF THE GRADE X STUDENTS OF

TKRB OF SMK N 1 SEDAYU

\begin{abstract}
This study was intended to improve the activeness of the students and the learning outcomes on Basic Technology of Automotive course in SMK N 1 Sedayu through the implementation of two stay two stray method. This type of research is classroom action
\end{abstract}


research (CAR) and was conducted in two cycles. The research design in each cycle uses four steps/stages of CAR as follows, (1) planning, (2) acting, (3) observing, and (4) reflecting. The research subjects are students of class X TKR B SMK N 1 Sedayu in even semester 2018/2019. Data collection process was conducted through the observation sheet to know how high the level of activeness of the students, and observe the implementation of two stay two stray method, and the evaluation test to know the level of student learning outcomes. The implementation of two stay two stray method successfully improves the activeness and the learning outcomes if the percentage of students activeness reaches $70 \%$ (good category) and as many as $75 \%$ of students have completed KKM (good category) namely the minimun score of learning outcomes is 75 . The result of the research points out that the implementation of two stay two stray method in the learning process could improve the activeness of the students and the learning outcomes of grade X students of TKR B in SMK N 1 Sedayu. This is proven in cycle II the percentage of students activeness and learning outcomes have been reached the success indicator determined with the percentage of activeness reaches $76 \%$ (good category) and students completed KKM reaches $81 \%$ (very good category).

Keywords: Activeness, Learning Outcomes, Two Stay Two Stray, CAR.

\section{PENDAHULUAN}

Pendidikan merupakan proses pemberian bekal berupa pengetahuan dan keterampilan, pengeluaran potensi anak yang dibawa waktu lahir, serta pemberian kecakapan kepada seseorang untuk masa depannya. Dalam undang-undang Nomor 20 tahun 2003 tentang sistem pendidikan nasional, pendidikan diartikan sebagai usaha sadar dan terencana untuk mewujudkan suasana belajar dan proses pembelajaran agar peserta didik secara aktif mengembangkan potensi dirinya untuk memiliki kekuatan spiritual keagamaan, pengendalian diri, kepribadian, kecerdasan, akhlak mulia, keterampilan yang diperlukan bagi dirinya, masyarakat bangsa dan negara.

SMK merupakan jenis pendidikan kejuruan di Indonesia yang termasuk jenjang pendidikan menengah dan bertujuan untuk menghasilkan lulusan berkompeten pada bidang kejuruan tertentu sesuai dengan program keahlian yang dipilih. Keberadaan SMK sangat penting untuk menyediakan sumber daya manusia khususnya tenaga kerja di industri. Hal ini sesuai dengan salah satu tujuan SMK yaitu untuk mengisi tenaga kerja di industri. Oleh karena itu, indikator SMK yang bermutu atau berkualitas dapat dilihat dari seberapa besar tingkatan kompetensi yang dimiliki peserta didik yang sesuai dengan kebutuhan di industri. Tingkat kompetensi tersebut dapat diketahui dan diukur melalui tes evaluasi/uji kompetensi baik teori maupun praktik yang kemudian dapat dinyatakan dalam bentuk nilai hasil belajar. 
SMK Negeri 1 Sedayu merupakan sekolah menengah kejuruan yang mempunyai visi menjadi lembaga pendidikan dan pelatihan di bidang teknologi yang berprestasi tingkat nasional/internasional. Untuk mewujudkan visi tersebut beberapa perubahan-perubahan telah dilaksanakan, salah satunya adalah mewujudkan branding sekolah berbasis industri melalui layanan pendidikan Link and Match bekerja sama dengan bidang industri. Melalui bekerja sama dengan industri maka layanan pendidikan kejuruan diberikan benar-benar sesuai dengan kebutuhan industri dan lulusannya bisa langsung terserap ke industri tersebut. Kerja sama yang sudah dilakukan adalah dengan PT. MAG. Selain itu, untuk mendukung proses belajar mengajar, pada tahun 2018 ini juga dilakukan perbaikan sarana prasarana berupa pembangunan 2 bangunan ruang kelas baru.

Meskipun berbagai usaha telah dilakukan untuk mengembangkan mutu atau prestasi di SMK N 1 Sedayu, dari hasil observasi yang dilakukan di kelas X TKRB pada mata pelajaran teknologi dasar otomotif masih ditemukan kurangnya keaktifan siswa dalam proses pembelajaran yang berdampak pada rendahnya hasil belajar siswa. Berdasarkan hasil observasi, diketahui pada proses pembelajaran guru sudah menggunakan pendekatan scientific dengan menerapkan lebih dari satu metode pembelajaran yaitu metode ceramah yang dipadu dengan metode diskusi. Walaupun sudah menggunakan pendekatan scientific dengan metode ceramah yang dipadu dengan metode diskusi, masih ada siswa yang tidak aktif dalam proses diskusi dan justru melakukan aktifitas-aktifitas diluar aktifitas belajar. Hal ini dapat dilihat dari 31 siswa yang ada dikelas, ditemukan sekitar 10 siswa yang berkonsultasi dengan guru didepan kelas, sedangkan siswa yang dibelakang ramai sendiri, 3 diantaranya bermain ponsel, 2 orang tertidur dan kurang dari 16 siswa X TKRB yang mengerjakan tugas. Kondisi ini menjadikan keaktifan siswa dalam proses belajar rendah.

Dari segi keluaran hasil belajar ditemukan semua siswa belum selesai mengerjakan pembahasan data hasil praktik beserta laporannya, padahal proses praktikum sudah berjalan 3 putaran dan laporan seharusnya sudah mulai dikumpul setiap minggunya. Saat dilakukan wawancara dengan siswa mengenai keterlambatan pengumpulan tugas atau laporan, siswa menjawab salah satunya dikarenakan masih bingung dengan tugas yang diberikan. Hal ini menunjukkan tingkat kepahaman siswa terhadap materi pelajaran masih rendah. Rendahnya tingkat pemahaman siswa terhadap materi pelajaran juga diperkuat apabila dilihat dari hasil penilaian tengah semester (PTS), dari 31 siswa rata-rata nilai kelas adalah 55 dengan jumlah siswa tuntas KKM sebanyak 2 orang.

Dari beberapa permasalahan yang dipaparkan diatas, permasalahan yang diangkat dalam penelitian ini adalah kurangnya tingkat kepahaman siswa terhadap materi pelajaran 
akibat rendahnya keaktifan siswa dalam proses belajar pada penggunaan metode ceramah yang dipadu dengan metode diskusi di SMK N 1 Sedayu. Hal ini dikarenakan apabila terus dibiarkan hasil belajar siswa akan berpotensi terus mengalami penurunan sehingga mengakibatkan turunnya mutu atau prestasi SMK Negeri 1 Sedayu dan berdampak terhadap lulusan dalam memasuki dunia kerja. Maka dari itu, penelitian ini difokuskan pada implementasi metode pembelajaran baru yang diduga mampu meningkatkan partisipasi aktif siswa dalam kegiatan belajar, yaitu Implementasi Metode Pembelajaran Two Stay Two Stray (TS-TS) untuk Meningkatkan Keaktifan dan Hasil Belajar TDO Siswa Kelas X TKRB SMK N 1 Sedayu. Kemudian masalah dalam penelitian ini dapat dirumuskan sebagai berikut: (1) apakah metode pembelajaran two stay two stray dapat meningkatkan keaktifan belajar siswa kelas X TKRB SMK N 1 Sedayu pada mata pelajaran teknologi dasar otomotif, dan (2) apakah metode pembelajaran two stay two stray dapat meningkatkan hasil belajar teknologi dasar otomotif siswa kelas X TKRB SMK N 1 Sedayu.

Tujuan penelitian ini adalah untuk meningkatkan keaktifan dan hasil belajar siswa kelas X TKR B SMK N 1 Sedayu pada mata pelajaran Teknologi Dasar Otomotif melalui implementasi metode pembelajaran two stay two stray. Pada penelitian ini dilakukan inovasi dari guru yang sebelumnya menggunakan metode ceramah yang dipadu dengan metode diskusi menjadi implementasi metode pembelajaran two stay two stray. Metode TS-TS merupakan salah satu tipe dari model pembelajaran kooperatif yang diharapkan dapat membuat peserta didik saling bekerja sama dan saling mendorong untuk aktif terlibat dalam proses berfikir selama proses pembelajaran berlangsung (Huda, 2015: 208). Karakteristik metode TS-TS yaitu pada kegiatan intinya dua orang siswa dari tiap kelompok berkunjung kesemua kelompok untuk mencari tahu hasil diskusi dan dua orang lainnya tetap tinggal dalam kelompok menjelaskan hasil diskusi kepada kelompok lain yang berkunjung, membuat setiap siswa/anggota kelompok mempunyai pembagian tugas kerja yang jelas sehingga meminimalkan siswa untuk melakukan aktifitas lain selain aktifitas belajar, dan diharapkan keaktifan siswa dalam proses belajar dapat lebih meningkat (Saefuddin \& Berdiati, 2014:164).

Hal ini diperkuat dengan hasil penelitian relevan yang dilakukan oleh Fatma Indah Rahmawati (2017) yang menunjukkan bahwa dengan mengimplementasikan metode two stay two stray pada proses pembelajaran dapat terjadi peningkatan keaktifan siswa dari awalnya pada siklus I rata-rata prosentase keaktifan belajar sebesar 53,64 \% meningkat pada siklus II menjadi $61,38 \%$. 
Keaktifan siswa dalam proses pembelajaran dapat diartikan sebagai aktifitas siswa dalam melakukan kegiatan belajar berupa kegiatan fisik dan psikis, kegiatan fisik berupa membaca, mendengar, menulis, berlatih keterampilan-keterampilan, dan kegiatan lainnya. Aspek kegiatan psikis berupa menggunakan ilmu pengetahuan yang dimiliki dalam memecahkan masalah, membandingkan suatu konsep dengan konsep yang lain, memberikan kesimpulan hasil percobaan, dan kegiatan psikis yang lainnya (Rusman, 2013: 101). Selain itu, keaktifan siswa dalam proses pembelajaran dapat dikelompokkan menjadi beberapa kegiatan: (1) kegiatan visual berupa membaca, mengamati, (2) kegiatan lisan berupa mengeluarkan pendapat, bertanya, mengemukakan hasil diskusi, menjawab pertanyaan, dan (3) kegiatan menulis berupa membuat catatan-catatan (Paul B. Diedrich dalam Hamalik, 2011: 172-173).

Adanya keaktifan merupakan tanda siswa sedang belajar, proses pembelajaran dapat berjalan apabila ada keaktifan dari siswa. Artinya, setiap orang yang belajar harus aktif sendiri, tanpa ada aktifitas, proses pembelajaran tidak akan terjadi (Rousseau dalam Sardiman, 2014: 95). Dengan siswa berpartisipasi aktif dalam proses belajar, menunjukkan bahwa siswa sedang terlibat dalam usaha belajarnya untuk memperoleh kemampuan tertentu yang ujungnya akan berkontribusi terhadap peningkatan hasil belajar. Hal ini sesuai dengan hasil penelitian yang dilakukan Herminarto Sofyan (2014) yang menunjukkan bahwa jika keaktifan siswa meningkat maka prestasi/hasil belajar juga akan meningkat.

Artinya, dengan menerapkan metode two stay two stray dalam proses pembelajaran akan meningkatkan keaktifan siswa dalam proses belajar, sehingga keterlibatan siswa dalam usaha belajarnya juga meningkat, dan pada akhirnya akan meningkatkan hasil belajar siswa. Hal ini sesuai dengan hasil penelitian relevan yang dilakukan Ervina Dika Tria Puspitasari (2016) yaitu bahwa dengan mengimplementasikan metode pembelajaran two stay two stray pada proses pembelajaran dapat terjadi peningkatan hasil belajar siswa dari rata-rata sebesar 68,23 pada siklus I kemudian naik menjadi 84,52 pada siklus II.

\section{METODE PENELITIAN}

Penelitian ini menggunakan model penelitian tindakan kelas (PTK). Model penelitian ini dipilih karena cocok diterapkan untuk meningkatkan keaktifan dan hasil belajar mata pelajaran teknologi dasar otomotif (TDO) di SMK N 1 Sedayu yang dilakukan melalui metode pembelajaran two stay two stray.

Desain penelitian disesuaikan dengan jenis penelitian yang digunakan, maka dalam pelaksanaannya, penelitian ini menggunakan langkah-langkah pada penelitian tindakan kelas 
mulai dari perencanaan, pelaksanaan tindakan, observasi dan refleksi. Empat langkah utama penelitian tindakan kelas tersebut dilakukan dan dikemas dalam setiap siklus.

Penelitian ini dilaksanakan di SMK N 1 Sedayu yang terletak di Jalan Kemusuk, Argomulyo, Sedayu, Bantul, Yogyakarta pada semester genap bulan Januari tahun ajaran 2018/2019. Subyek penelitian adalah siswa kelas X TKRB SMK N 1 Sedayu pada mata pelajaran teknologi dasar otomotif.

Instrumen yang digunakan dalam penelitian ini yaitu lembar observasi untuk mengetahui keaktifan siswa, dan mengamati pelaksanaan metode two stay two stray, serta tes evaluasi untuk mengetahui tingkat pemahaman/hasil belajar siswa setelah diterapkan pembelajaran dengan metode two stay two stray. Jenis tes yang digunakan dalam penelitian ini adalah tes pilihan ganda untuk mengetahui hasil belajar siswa pada siklus I dan siklus II. Agar terjadi kesetaraan tingkat kesulitan antara soal siklus I dan siklus II, maka distribusi tingkat kesulitan soal pada siklus I dan II juga dibuat sama, yaitu terdiri dari $25 \%$ soal mudah (C1), $50 \%$ soal sedang (C2 dan C3), dan 25\% soal sulit (C4). Jenis validitas yang digunakan untuk instrumen soal tes adalah validitas konstrak dan validitas isi.

Data yang dikumpulkan melalui instrumen penelitian berupa angka atau data kuantitatif. Teknik analisis datanya masing-masing adalah sebagai berikut,

\section{Persentase Keaktifan Belajar Siswa}

$$
P K(\%)=\frac{a}{n \times b} \times 100 \%
$$

\section{Keterangan,}

PK = Persentase keaktifan belajar dari seluruh siswa dalam satu kelas

a = Jumlah indikator keaktifan siswa yang muncul

$\mathrm{n} \quad=$ Jumlah siswa

$\mathrm{b} \quad=$ Jumlah keseluruhan indikator keaktifan 


\section{Penentuan Kategori Keaktifan Belajar}

Tabel 1. Kategori Keaktifan Belajar Siswa

\begin{tabular}{cc}
\hline Persentase Keaktifan & Kriteria \\
\hline $80-100 \%$ & Sangat Baik \\
$66-79 \%$ & Baik \\
$56-65 \%$ & Cukup \\
$40-55 \%$ & Kurang \\
$<40 \%$ & Kurang Sekali \\
\hline
\end{tabular}

(Arikunto \& Jabar, 2014: 35)

\section{Persentase Ketuntasan Hasil Belajar Siswa}

SMK N 1 Sedayu menerapkan KKM sebesar 75 untuk mata pelajaran TDO

Ketuntasan $(\%)=\frac{J m l \text { siswa tuntas }}{\text { Jumlah siswa }} \times 100$

\section{Rata-rata Hasil Belajar Siswa}

Mean $=\frac{\text { Jumlah nilai dalam satu kelas }}{\text { Jumlah siswa }}$

\section{Penentuan Kategori Ketuntasan Hasil Belajar}

Tabel 2. Kategori Hasil Belajar Siswa

\begin{tabular}{cc}
\hline Persentase Ketuntasan & Kriteria \\
\hline $80-100 \%$ & Sangat Baik \\
$66-79 \%$ & Baik \\
$56-65 \%$ & Cukup \\
$40-55 \%$ & Kurang \\
$<40 \%$ & Kurang Sekali \\
\hline
\end{tabular}

(Arikunto \& Jabar, $2014 ; 35$ ) 


\section{Kesesuaian Pelaksanaan Metode Two Stay Two Stray}

\section{Keterangan}

$$
P(\%)=\frac{n G}{n S} \times 100
$$

$\mathrm{P} \quad=$ Persentase Kesesuaian

$\mathrm{nG} \quad=$ Jumlah langkah pembelajaran yang dilakukan guru sesuai sintak

$\mathrm{nS} \quad=$ Jumlah semua langkah pembelajaran pada sintak metode TS-TS

Indikator keberhasilan implementasi metode two stay two stray untuk meningkatkan keaktifan belajar siswa adalah apabila setelah diterapkan metode tersebut jumlah persentase keaktifan siswa dalam satu kelas minimal mencapai 70\%. Pemilihan indikator ini berdasarkan tabel kategori keaktifan belajar siswa dimana persentase $70 \%$ menunjukkan keaktifan belajar siswa pada kategori "Baik". Sedangkan indikator keberhasilan untuk meningkatkan hasil belajar siswa adalah apabila setelah diterapkan metode tersebut, jumlah persentase ketuntasan hasil belajar siswa mencapai minimal $75 \%$ dari jumlah seluruh siswa dikelas. Pemilihan indikator keberhasilan ini didasari oleh tabel kategori hasil belajar siswa dimana persentase 75\% menunjukkan hasil belajar siswa pada kategori "Baik", dan dari aspek pembelajaran dapat dikatakan berhasil jika siswa telah tuntas KKM setidak-tidaknya 75\% dari seluruh siswa dalam kelas (Mulyasa, 2014: 131).

\section{HASIL PENELITIAN DAN PEMBAHASAN}

Penelitian ini dilaksanakan selama dua siklus. Mata pelajaran yang digunakan selama penelitian adalah teknologi dasar otomotif (TDO) pada kompetensi dasar (KD) 3.11 Memahami rangkaian kelistrikan sederhana dan kompetensi dasar (KD) 3.15 Mengevaluasi kerja baterai. Dalam pelaksanaannya, setiap siklus penelitian ini menggunakan langkahlangkah penelitian tindakan kelas yaitu mulai dari perencanaan tindakan, pelaksanaan tindakan, observasi tindakan dan refleksi tindakan.

Siklus I berhasil dilaksanakan selama 3 kali pertemuan. Kegiatan pembelajaran yang dilakukan guru yaitu pertama mengenalkan metode pembelajaran yang akan dipakai yaitu metode two stay two stray beserta aturan dan penilaian yang akan dilaksanakan, kemudian guru membagi siswa menjadi 8 kelompok secara urut (kelompok A sampai dengan kelompok $\mathrm{H}$ ) setiap kelompok terdiri dari 4 siswa. Setelah kelompok terbentuk, guru memberikan materi pendahuluan, memotivasi peserta didik melalui kegiatan tanya jawab, kemudian membagi topik-topik diskusi masing-masing kelompok. Topik yang didiskusikan adalah aliran listrik, 
efek yang ditimbulkan listrik, besaran listrik \& hukum ohm, rangkaian (seri paralel, gabungan), daya dan kerja listrik.

Setelah guru membagi materi diskusi, masing-masing kelompok kemudian mendiskusikannya. Kegiatan selanjutnya, guru meminta 2 orang siswa pada masing-masing kelompok menuju kelompok lainnya untuk mencari tahu hasil diskusi kelompok lain tersebut, sedangkan 2 orang siswa lainnya tetap tinggal dalam kelompok menjelaskan hasil kerja kelompok kepada teman yang berkunjung. Pada tahap ini waktu setiap kunjungan adalah 5 menit.

Setelah kegiatan berkunjung selesai, guru mengkondisikan siswa kembali kekelompoknya masing-masing untuk membahas hasil kerja yang telah mereka kerjakan. Pada tahap ini, guru mengarahkan agar dua orang siswa yang berkunjung kesemua kelompok, menjelaskan hasil temuannya kepada siswa yang tinggal dalam kelompok. Kegiatan pada pertemuan terakhir siklus I diakhiri dengan mengerjakan soal evaluasi hasil belajar berupa soal pilihan ganda sebanyak 25 soal dengan durasi waktu mengerjakan soal selama 40 menit.

Ada tiga langkah dari metode TS-TS yang belum dilaksanakan pada siklus I ini, yaitu tahap presentasi, tanya jawab, dan menyimpulkan pembelajaran yang telah dilakukan. Hal ini disebabkan pada pertemuan terakhir siklus I belum dilaksanakan tahap presentasi sebagaimana sintak metode TS-TS, melainkan para siswa maju kedepan kelas untuk mengerjakan soal dipapan tulis secara bergantian, selain itu waktu pelajaran juga terbatas sehingga tidak mencukupi untuk dilakukannya tahap menyimpulkan pembelajaran yang telah dilakukan. Pada siklus II semua langkah metode TS-TS termasuk ketiga langkah tersebut dapat terlaksana. Ketiga langkah daripada metode TS-TS tersebut dapat terlaksana setelah dilakukan diskusi dan perancangan proses presentasi dan tanya jawab dengan guru pengampu pada tahap perencanaan siklus II, dan setelah dilakukannya pembagian waktu yang efektif sehingga mencukupi untuk dilaksanakannya tahap menyimpulkan materi yang telah dipelajari.

Setelah diterapkan metode TS-TS terjadi perubahan keaktifan siswa selama proses pembelajaran. Adapun besarnya keaktifan siswa setelah diterapkan metode TS-TS pada siklus I dan II dapat dilihat masing-masing pada tabel 3, gambar 1, dan gambar 2. 
Tabel 3. Keaktifan siswa pada proses pembelajaran

\begin{tabular}{lcc}
\hline \multirow{2}{*}{ Indikator } & \multicolumn{2}{c}{ Kemunculan } \\
\cline { 2 - 3 } & Siklus I & Siklus II \\
\hline Mengamati penjelasan dari guru (Indikator A) & 24 & 25 \\
Membaca materi pelajaran (Indikator B) & 14 & 21 \\
Mengeluarkan pendapat (Indikator C) & 6 & 15 \\
Mengemukakan hasil diskusi kelompok (Indikator D) & 19 & 21 \\
Mengamati penjelasan dari teman (Indikator E) & 12 & 24 \\
Membuat catatan-catatan tentang materi pelajaran (Indikator F) & 22 & 26 \\
Mengajukan pertanyaan (Indikator G) & 14 & 14 \\
Menjawab pertanyaan (Indikator H) & 11 & 13 \\
Jumlah & 122 & 159 \\
\hline
\end{tabular}

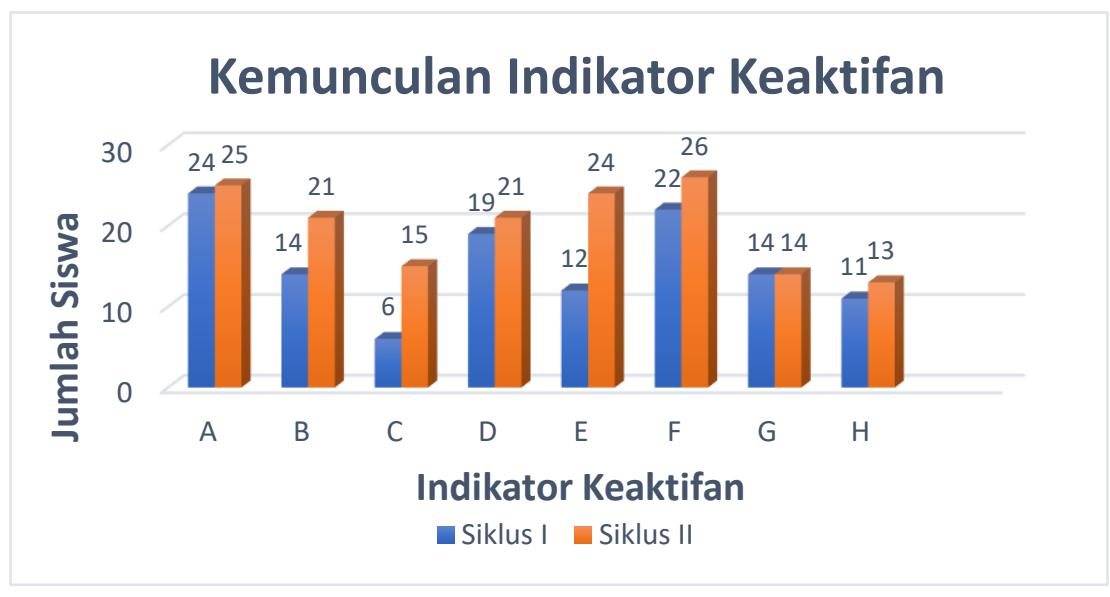

Gambar 1. Diagram Batang Kemunculan Indikator Keaktifan

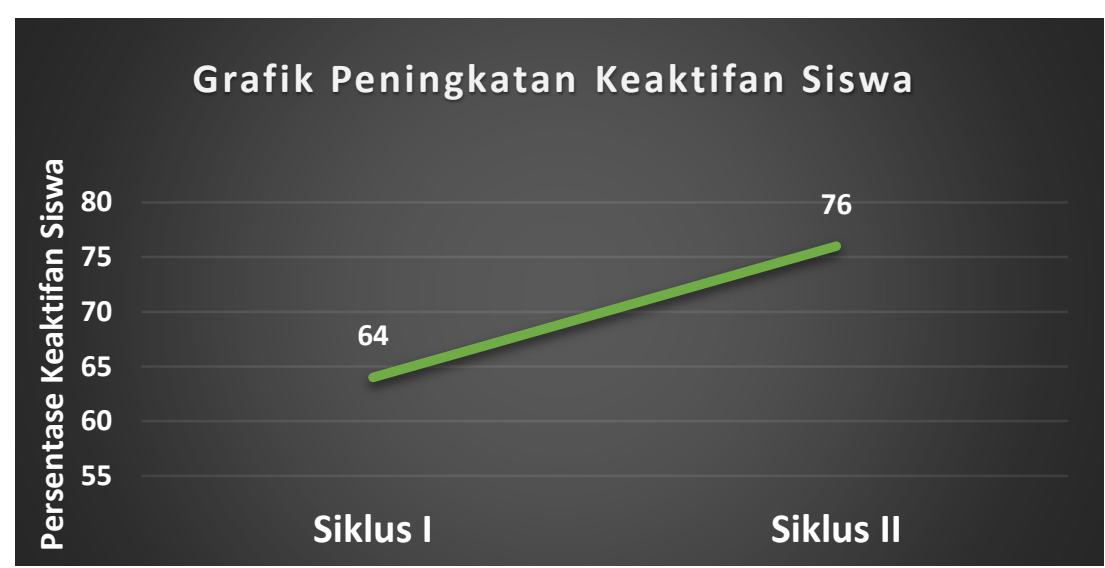

Gambar 2. Grafik Peningkatan Keaktifan Belajar Siswa 
Berdasarkan gambar 2 dapat dilihat pada siklus I persentase keaktifan mencapai $64 \%$. Artinya pada siklus I ini indikator keberhasilan tindakan belum tercapai. Penyebab ketidak keberhasilan yaitu: (1) belum terlaksananya tahap presentasi dan tanya jawab yang menyebabkan keaktifan siswa dalam mengeluarkan pendapat (Indikator C) dan siswa menjawab pertanyaan (Indikator H) menjadi sedikit kemunculannya, (2) Terdapat sejumlah 5 kelompok dimana dua siswa yang berkunjung dari kelompok tersebut lebih suka langsung mencatat daripada mendengarkan penjelasan dari teman terlebih dahulu karena banyaknya materi hasil diskusi yang dipaparkan sedangkan waktu berkunjung terbatas hanya 5 menit. Hal ini menyebabkan keaktifan siswa dalam mengamati penjelasan dari teman (Indikator E) menjadi sedikit pengaplikasiannya.

Setelah dilakukan perbaikan terhadap kekurangan-kekurangan tersebut pada siklus II, keaktifan siswa meningkat sebanyak $12 \%$ menjadi sebesar $76 \%$ dan melebihi indikator keberhasilan yang ditentukan. Dari penjelasan tersebut dapat diketahui bahwa implementasi metode two stay two stray dalam proses belajar dapat meningkatkan keaktifan belajar siswa di kelas X TKR B SMK N 1 Sedayu, sehingga berhasil mengatasi permasalahan penelitian berupa rendahnya tingkat keaktifan siswa selama proses pembelajaran. Hal ini sesuai dengan teori yang dikemukakan Huda (2015:208) yaitu metode TS-TS dapat memberikan kesempatan pada siswa untuk saling membelajarkan dan saling mendukung, bertujuan memberikan kesempatan kepada siswa untuk dapat terlibat secara aktif dalam proses berfikir. Keberhasilan implementasi metode TS-TS untuk meningkatkan keaktifan belajar siswa pada penelitian ini juga mendukung penelitian relevan sebelumnya yang dilakukan oleh Fatma Indah Rahmawati (2017) dengan judul "Penerapan Model Pembelajaran Kooperatif Tipe two stay two stray untuk Meningkatkan Keaktifan dan Hasil Belajar Sistem Komputer Siswa Kelas X TKJ A SMK N 2 Klaten", hasil penelitian tersebut menunjukkan bahwa terdapat peningkatan keaktifan belajar siswa setelah mengimplementasikan metode TS-TS dalam proses pembelajaran.

Pada segi hasil belajar juga terdapat peningkatan dari siklus I ke siklus II, baik dari ratarata hasil belajar maupun ketuntasan hasil belajar. Perubahan tingkat hasil belajar siswa dapat dilihat pada tabel 4 dan gambar 3 berikut.

Tabel 4. Hasil Belajar Siklus I dan II

\begin{tabular}{lcc}
\hline \multicolumn{1}{c}{ Hasil Belajar } & Siklus I & Siklus II \\
\hline Jumlah siswa tuntas KKM & 10 & 21 \\
Rata-rata nilai kelas & 70 & 80 \\
Persentase Ketuntasan & $42 \%$ & $81 \%$ \\
\hline
\end{tabular}




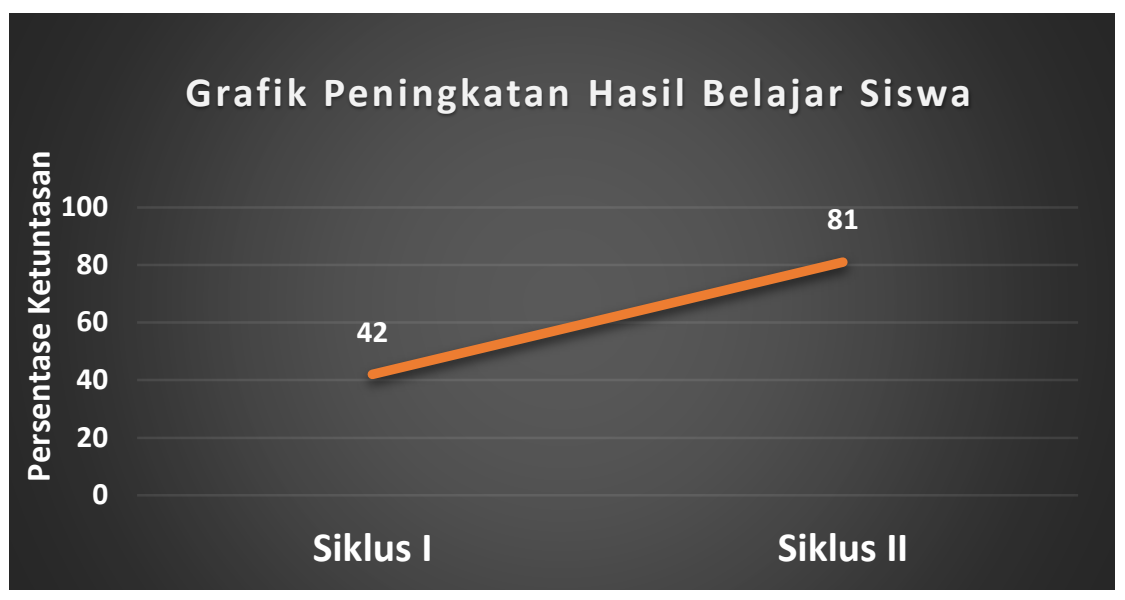

Gambar 3. Grafik Peningkatan Hasil Belajar Siswa

Dari gambar grafik tersebut, diketahui pada siklus I, indikator keberhasilan tindakan untuk hasil belajar belum terpenuhi. Penyebab ketidak keberhasilan yaitu: (1) Belum efektifnya tahap pembahasan hasil kerja dimana siswa yang berkunjung tidak maksimal dalam menjelaskan, bahkan hanya meminta temannya yang tinggal dikelompok untuk langsung mencatat saja apa yang mereka dapat. Hal ini menyebabkan pemahaman siswa menjadi timpang sebelah, (2) Belum terlaksananya sesi tanya jawab, membuat siswa yang masih bingung mengenai beberapa aspek dari materi pelajaran menjadi tidak terungkap yang akhirnya siswa menjadi tidak paham terhadap materi tersebut. Setelah dilakukan perbaikan terhadap kekurangan-kekurangan tersebut, pada siklus II hasil belajar siwa meningkat dan melebihi indikator keberhasilan yang ditentukan.

Peningkatan hasil belajar ini apabila dilihat dari kondisi awal ke siklus I, dan dari siklus I ke siklus II selalu mengikuti peningkatan dari keaktifan siswa. Artinya semakin tinggi keaktifan siswa maka hasil belajar juga semakin tinggi. Hal ini dikarenakan dengan siswa berpartisipasi aktif dalam proses belajar, menunjukkan bahwa siswa sedang terlibat dalam usaha belajarnya untuk memperoleh kemampuan tertentu yang ujungnya akan berkontribusi terhadap peningkatan hasil belajar, apabila keaktifan siswa dalam proses belajar meningkat, maka keterlibatan siswa dalam usaha belajarnya juga meningkat dan pada akhirnya akan meningkatkan hasil belajar. Hal ini juga diperkuat dengan pendapat Rousseau dalam Sardiman (2014:95) yang menyatakan bahwa, "Setiap orang yang belajar harus aktif sendiri, tanpa ada aktifitas, proses pembelajaran tidak akan terjadi”. Dari pendapat tersebut diketahui bahwa apabila siswa semakin aktif maka siswa semakin melakukan kegiatan belajar sehingga hasil 
belajarnya juga akan semakin baik. Namun sebaliknya apabila siswa tidak aktif maka dapat dikatakan siswa tidak melakukan kegiatan belajar.

Keberhasilan implementasi metode TS-TS untuk meningkatkan hasil belajar siswa pada penelitian ini juga mendukung penelitian relevan sebelumnya yang dilakukan oleh Ervina Dika Tria Puspitasari (2016) dengan judul "Implementasi Model Pembelajaran Kooperatif Tipe two stay two stray untuk Meningkatkan Aktifitas dan Hasil Belajar Siswa Kelas X Teknik Audio Video pada Mata Pelajaran Teknik Elektronika Dasar di SMK N 3 Wonosari, hasil penelitian relevan tersebut menunjukkan bahwa terdapat peningkatan hasil belajar siswa setelah mengimplementasikan metode TS-TS dalam proses pembelajaran.

\section{SIMPULAN}

Berdasarkan hasil penelitian dan pembahasan dapat ditarik kesimpulan bahwa implementasi metode two stay two stray dalam proses belajar pada mata pelajaran Teknologi Dasar Otomotif Kelas X TKR B SMK N 1 Sedayu dapat meningkatkan keaktifan dan hasil belajar siswa sehingga dapat mengatasi permasalahan di SMK N 1 Sedayu berupa rendahnya keaktifan dan hasil belajar. Pada awalnya dari 31 siswa yang ada dikelas ditemukan sekitar 10 siswa yang bertanya/berkonsultasi dengan guru didepan kelas, sedangkan yang lain melakukan kegiatan diluar aktifitas belajar, artinya keaktifan siswa dalam proses belajar rendah yaitu sebesar $32 \%$. Setelah diterapkan metode two stay two stray pada siklus I keaktifan siswa meningkat dengan persentase keaktifan kelas sebesar 64\% dan kembali meningkat pada siklus II menjadi $76 \%$.

Dari segi hasil belajar, awalnya persentase ketuntasan siswa sebesar 6,3\% dengan ratarata nilai kelas sebesar 55. Setelah diterapkan metode two stay two stray ketuntasan hasil belajar meningkat pada siklus I menjadi $42 \%$ dengan rata-rata nilai kelas sebesar 70 dan kembali meningkat pada siklus II menjadi $81 \%$ dengan rata-rata nilai kelas sebesar 80. Dari hasil tersebut diketahui naiknya keaktifan siswa dalam proses belajar juga diikuti oleh naiknya hasil belajar siswa. Hal ini dikarenakan semakin besar keaktifan siswa menunjukkan siswa semakin terlibat dalam proses belajar sehingga dapat meningkatkan hasil belajarnya.

\section{DAFTAR PUSTAKA}

Arikunto, S. \& Jabar, C.S.A (2014). Evaluasi Program Pendidikan. Jakarta: Bumi Aksara Depdikbud. (2003). Undang-undang RI Nomor 20, Tahun 2003, tentang Sistem Pendidikan Nasional. 
Ervina Dika Tria Puspitasari (2016). Implementasi Model Pembelajaran Kooperatif Tipe Two Stay Two Stray Untuk Meningkatkan Aktifitas Dan Hasil Belajar Siswa Kelas X Teknik Audio Video pada Mata Pelajaran Teknik Elektronika Dasar Di SMK N 3 Wonosari. Skripsi. UNY

Fatma Indah Rahmawati (2017). Penerapan Model Pembelajaran kooperatif tipe Two Stay Two Stray (TS-TS) Untuk Meningkatkan Keaktifan Dan Hasil Belajar sistem komputer Siswa Kelas X TKJ A SMK Negeri 2 Klaten. Skripsi. UNY

Hamalik, O. (2011). Proses Belajar Mengajar. Jakarta: Bumi Aksara

Herminarto Sofyan, Tawardjono Usman, dan Gunadi. (2014). Peningkatan Mutu Pembelajaran Teknologi Pengecatan Melalui Metode Jigsaw Bagi Mahasiswa Otomotif FT UNY. Jurnal JPTK Vol 22 Mei 2014. Yogyakarta: FT UNY

Huda, M. (2015). Model-model Pengajaran dan Pembelajaran: Isu-isu Metodis dan Paradigmatis. Yogyakarta: Pustaka Pelajar.

Mulyasa, H.E. (2014). Pengembangan dan Implementasi Kurikulum 2013. Bandung: PT. Remaja Rosdakarya Offset

Rusman. (2013). Belajar dan Pembelajaran Berbasis Komputer Mengembangkan Profesionalitas Guru Abad 21. Bandung: Alfa Beta.

Saefuddin, H.A. \& Berdiati, I. (2014). Pembelajaran Efektif. Bandung: PT. Remaja Rosdakarya Offset

Sardiman, A.M. (2014). Interaksi \& Motivasi Belajar. Bandung: Rajawali Press. 